\title{
STRATEGI PENGENDALIAN IMPOR HORTIKULTURA
}

\author{
Iskandar Andi Nuhung *
}

\begin{abstract}
ABSTRAK
Selama ini konsumsi hortikultura masyarakat Indonesia relatif masih rendah jika dibandinggan negara Asean lainnya apalagi jika dibanding dengan negara maju seperti AS,Eropa dan Jepang. Sehingga dengan kenaikan pendapatan masyarakat mereka meningkatkan konsumsi produk hortikultura (dalam teori ekonomi disebut marginal propensity to consume =MPC masyarakat meningkat). Komoditi hortikultura buah dan sayuran yang memiliki elastisitas permintaan cukup tinggi, mengisyaratkan bahwa semakin tinggi tingkat pendapatan seseorang maka permintaan akan barang tersebut akan semakin naik pula. Oleh karena itu adalah suatu hal yang normal dan alami jika terjadi impor hortikultura ketika laju pertumbuhan permintaan lebih besar dari laju pertumbuhan suply dari produksi dalam negeri. Indonesia sebagai negara tropis dan agraris, meskipun memiliki potensi sumber daya alam dan kekayaan genetik yang besar, namun tetap saja harus mengimpor produk pertanian tertentu termasuk produk hortikultura untuk memenuhi kebutuhan permintaan dalam negeri. Dalam era globalisasi saat ini, perdagangan barang dan jasa termasuk produk hortikultura, dihadapkan pada tantangan untuk menghadapi persaingan yang semakin ketat. Bagi negara berkembang seperti Indonesia yang memiliki potensi sumber daya alam yang besar untuk pengembangan hortikultura,dituntut untuk membangun dan mengembangkan strategi untuk mengendalikan impor produk-produk hortikultura, untuk memberi ruang gerak yang leluasa bagi produk dalam negeri untuk menjadi pemain utama di pasar domestik, baik karena pertimbangan ekonomi, sosial, dan kemandirian bangsa. Strategi promosi dan proteksi yang disederhanakan menjadi lima upaya pengendalian impor hortikultura perlu dirumuskan aplikasi dan operasionalisasinya, yang dipedomani oleh semua pihak di pusat dan daerah. Melalui strategi tersebut diharapkan produk hortikultura nasional dapat menjadi tuan dirumah sendiri, karena memiliki kemampuan bersaing yang tinggi.
\end{abstract}

Kata kunci : hortikultura, impor, produksi, tarif

\begin{abstract}
Indonesia's consumption of horticultural products is still relatively low compared with other Asean countries especially with developed countries such as the US, Europe and Japan. So with the increase in people's income, people increase the consumption of horticultural products (in economic theory called the marginal propensity to consume $=M P C$ increases
\end{abstract}


society). Horticulture fruit and vegetables that have high demand elasticity, hinted that the higher the level of a person's income, the demand for goods will further increase as well. Therefore, it is a normal and natural thing in case of horticultural imports when demand growth is greater than the growth rate of supply from domestic production. Indonesia as a tropical country and agriculture although it has the potential of natural resources and wealth of great genetic, but it still have to import of certain agricultural products including horticultural products to meet domestic demand. In the current era of globalization, trade in goods and services, including horticultural products, challenge by increasingly fierce competition. For developing countries like Indonesia, which has the potential of natural resources which is great for the development of horticulture, it is required to build and develop a strategy for controlling imports of horticultural products, to provide breathing space freely for domestic products to become a major player in the domestic market, either due consideration of the economic, social, and national independence. Promotion and protection strategies are simplified into five horticultural import control measure s and it needs to be formulated the application and operation, which is guided by all parties in the center and regions. Through this strategy, it is expected horticultural products can be hosted at domestic level, due to its high ability to compete.

Keywords: horticulture, import, production, tariff

\section{PENDAHULUAN}

Impor produk pertanian bukan hal baru bagi Indonesia, sudah berlangsung lama dan pertimbangannya rasional, bahwa kebutuhan dalam negeri yang meningkat dan tidak bisa dipenuhi dari produksi dalam negeri. Kecenderungan meningkatnya impor produk pertanian searah dengan semakin meningkatnya pendapatan masyarakat, semakin bertambahnya jumlah penduduk, semakin berkembangnya tehnologi sehingga memungkinkan dilakukannya diversifikasi produk dan mamfaat produk pertanian. Sebagai contoh dari diversifikasi mamfaat produk pertanian dengan perkembangan tehnologi adalah pemamfaatan produk pertanian untuk sumber energi baru dan terbarukan. Hal ini telah menimbulkan debat dikotomi antara energi dan pangan. Perkem bangan lebih lanjut terjadi bahwa laju pertumbuhan permintaan akan produk pertanian di dalam negeri lebih cepat dibanding dengan laju suplly dari produksi dalam negeri, sehingga ketergantungan akan impor semakin besar terhadap beberapa produk pertanian.

Sepanjang sejarah, komoditi pertanian yang selalu defisit dalam perdagangannya adalah hortikultura dan komoditas pangan, dan dalam dua dekade terakhir juga terjadi pada produk ternak. Komoditi perkebunan merupakan penyumbang terbesar dalam neraca perdagangan pertanian. 
Tabel 1. Ekspor Impor Komoditi Pertanian Indonesia

\begin{tabular}{ccccccc}
\hline \multirow{2}{*}{ Tahun } & \multicolumn{3}{c}{ Volume (000 ton) } & \multicolumn{3}{c}{ Nilai (Juta US\$) } \\
\cline { 2 - 7 } & Ekspor & Impor & Neraca & Ekspor & Impor & Neraca \\
\hline 2007 & 23.955 & 15.921 & 8.033 & 21.240 & 8.615 & 12.624 \\
2008 & 27.300 & 12.593 & 14.561 & 29.300 & 11.341 & 17.959 \\
2009 & 29.572 & 13.401 & 16.171 & 23.037 & 9.897 & 13.140 \\
2010 & 28.768 & 16.874 & 11.893 & 32.522 & 13.983 & 18.539 \\
2011 & 29.959 & 22.917 & 7.041 & 43.365 & 20.598 & 22.768 \\
\hline
\end{tabular}

Sumber : Statistik Pertanian, 2012

Kalau kita perhatikan tabel 1 tersebut, terlihat bahwa Indonesia senantiasa menikmati surplus dari perdagangan hasilhasil pertanian. Sumbangan surplus tersebut diperoleh dari komoditas perkebunan, terutama kelapa sawit, karet dan coklat. Yang menarik bahwa nilai impor komoditi pertanian cenderung meningkat dalam lima tahun terakhir. Kenaikan nilai impor tersebut terutama terjadi pada pangan dan ternak dan sebagian komoditi hortikultura. Beberapa komoditi bahkan semakin tergantung pada impor dalam jumlah atau prosentase yang sangat besar seperti terlihat pada tabel 2 .

Tabel 2 : Presentase impor beberapa komoditi pertanian.

\begin{tabular}{lr}
\hline \multicolumn{1}{c}{ Komoditi } & \% Impor \\
\hline Kapas & 9.89 \\
Gula & 30 \\
Jagung & 10.25 \\
Kedelai & 75 \\
Kacang tanah & 15 \\
Bawang Putih & 90 \\
Daging sapi & 25 \\
Gandum & 100 \\
\hline Sumber, BPS, 2012 (diolah) &
\end{tabular}

Data tersebut menunjukkan bahwa, Indonesia sudah sejak lama tergantung pada impor beberapa produk pertanian untuk memenuhi kebutuhan konsumsi dalam negeri. Beberapa komoditi lainnya sebetulnya juga diimpor, meskipun Indonesia tercatat sebagai eksportir komoditi tersebut, seperti kopi, teh, coklat, beras, ubi kayu, tanaman obat-obatan, sayuran, dan bunga-bungaan. Khusus untuk komoditas hortikultura, kenaikan impor mengundang perhatian berbagai kalangan bukan karena jumlah dan nilainya yang semakin membesar, tapi juga karena komoitas tersebut dapat diproduksi secara besar-besaran di dalam negeri.

\section{PERKEMBANGAN HORTIKULTURA NASIONAL.}

Kerisauan, keprihatinan dan bahkan kepanikan terhadap fenomena semakin meningkatnya impor hortikultura dari 787,86 juta US dollar tahun 2007 meningkat menjadi 1,76 milyar US dollar atau sekitar Rp.17 trilyun tahun 2011 (angka yang tercatat di BPS,yg tidak tercatat angkanya juga cukup besar), sebetulnya tidak perlu terjadi jika kita bisa secara jernih melihat duduk persoalannya 
dan mengambil sisi positifnya. Peningkatan impor tersebut sebaiknya disikapi secara arif bijaksana dan mengambil hikmah sekaligus sebagai masukan untuk melakukan introspeksi kinerja bangsa ini dalam membangun hortikultura nasional. Kenaikan impor itu secara sederhana juga dapat diterjemahkan bahwa kesejahteraan orang Indonesia semakin membaik dan kita harus mensyukurinya., Sama halnya dengan semakin banyaknya mobil dan sepeda motor dijalanan meskipun menimbulkan kemacetan, jangan disalahkan mobil atau motornya tapi managemen transportasi yang harus diperbaiki. Demikian pula halnya ketika pasar hortikultura dalam negeri dibanjiri oleh produk-produk impor, tidak perlu dicari siapa yang salah, karena hanya akan menghabiskan energi. Impor itu tidak haram, bahkan dalam era penerapan perjanjian WTO yang telah bergulir selama ini, negara-negara didunia ini harus membuka pasar produk pertaniannya termasuk pasar produk hortikultura. Memang ada pengecualian-pengecualian yang ditujukan untuk membantu negaranegara berkembang, tapi itupun memiliki jangka waktu,dan setelah melewati fase tersebut negara-negara berkembang harus menerima equal treatment dari ketentuanketentuan yang telah disepakati WTO. Artinya suka atau tidak suka pada akhirnya perdagangan atau pasar bebas itu pasti akan berlaku universal. Mungkin memang yang membuat kita prihatin karena ternyata nilai impor itu cenderung semakin meningkat dari tahun-ketahun, sehingga defisit neraca perdagangan produk hortikultura juga semakin membengkak. Beberapa faktor yang menyebabkan maraknya impor produk hortikultura antara lain, 1) produksi hortikultura dalam negeri baik jumlah maupun mutunya tidak mencukupi kebutuhan permintaan konsumsi dalam negeri yang cenderung terus meningkat karena peningkatan pendapatan masyarakat dan pertambahan penduduk, 2) terdapat beberapa jenis komoditi hortikultura yang merupakan komoditi sub tropis, sehingga tidak bisa tumbuh dengan baik di daerah tropis seperti Indonesia,sehingga untuk memenuhi permintaan masyarakat harus dilakukan melalui impor, 3) perhatian dan dukungan pemerintah untuk pengembangan hortikultura rendah terutama alokasi anggaran untuk pengembangan dan pembinaan, baik dalam bentuk APBN/APBD, kredit perbankan dan investasi PMDN/PMA, dan 4) pengelolaan pembangunan hortikultural baik ditinjau dari sudut kelembagaan, perencanaan, kordinasi dan partisipasi semua pihak relatif masih lemah dan miskin terobosan, meskipun telah ada undang-undang hortikultura sejak empat tahun yang lalu. Pada tabel 3 dapat dilihat produksi komoditas hortikultura tahun 2007-2011.

Keprihatinan terhadap impor hortikultura juga menyentuh hati masyarakat petani, yang selama ini telah berjuang untuk mengembangkan produk hortikultura, tapi tidak mendapat apresiasi dari pemerintah yang dibuktikan dengan peningkatan impor. Indonesia yang memiliki potensi sumber daya alam yang sangat besar, sangat berpeluang untuk mengembangkan hiortikultura yangselama ini diimpor. Hanya saja atensi pemerintah 
untuk mengambangkannya relatif rendah, sehingga selain produksi rendah juga perlakuan tehnologi sangat terbatas sehingga kualitas produksi juga rendah sehingga tidak mampu bersaing dengan produk impor.Beberapa produk hortikultura yang potensil dikmbankan, namun dalam kenyataannya harus diimpor untuk memenuhi kebutuhan masyarakat seperti, bawan putih, bawang merah, jeruk, pisang, mangga, cabe, biofarmaka dan bungabungaan.

Indonesia tidak hanya mengimpor produk hortikultura, tapi juga mengimpor benih atau bibit hortikultura terutama untuk sayuran. Hal ini telah menghambat pengembangan penangkar benih hortikultura dalam negeri. Bibit unggul dan hibrida hortikultura banyak didatangkan dari luar negeri untuk dikembangkan di Indonesia seprti yang banyak dijumpai di Jawa Barat. Benih sayuran impor tersebut sebagian besar adalah sayuran ekslusif untuk mengisi pasar modern.

Dari data tersebut menunjukkan bahwa, tidak hanya nilai import hortikultura yang meningkat, tapi yang perlu dicermati bahwa defisit neraca perdagangan produk hortikultura juga meningkat, dan nilai eksport ada kecenderungan mengalami penurunan.

Tabel 3 : Produksi komoditas hortikultura Indonesia 2007-2011 (ton)

\begin{tabular}{ccccc}
\hline Tahun & Sayuran & Buah-buahan & Tan. Hias* & Biofarmaka \\
\hline 2007 & 9.455 .462 & 17.116 .622 & 179.374 .218 & 444.201 \\
2008 & 10.035 .093 & 18.027 .889 & 205.564 .659 & 398.808 \\
2009 & 10.628 .285 & 18.653 .900 & 263.531 .374 & 408.157 \\
2010 & 10.706 .386 & 15.490 .373 & 378.915 .785 & 351.154 \\
2011 & 10.871 .224 & 18.313 .507 & 486.851 .880 & 316.572 \\
\hline
\end{tabular}

Sumber ; Statistik Pertanian, Kementerian Pertanian, 2012.

*) dalam bentuk tangkai/stek

Tabel 4 : nilai ekspor-impor hortikultura (juta US dollar)

\begin{tabular}{cccc}
\hline Tahun & Ekspor & Impor & Defisit \\
\hline 2007 & 254,5 & 810,1 & 555,6 \\
2008 & 433,9 & 926,0 & 492,1 \\
2009 & 261,2 & 606,8 & 345,6 \\
2010 & 297,9 & 655,4 & 357,5 \\
2011 & 435,6 & 829,0 & 393,4 \\
2012 & 401,9 & 847,7 & 445,8 \\
\hline
\end{tabular}

Sumber : Kementerian Perdagangan,2013 
Yang menarik adalah bahwa angka defisit neraca perdagangan kamoditi hortikultura tahun 2012, menyumbang lebih dari $30 \%$ terhadap defisit neraca perdagangan nasional pada tahun yang sama yang mencapai 1,660 milyar US dollar. Angka ini tentu bisa menjadi polemik sekaligus memprihatinkan, terutama karena Indonesia yang selalu dijuluki sebagai negara agraris, namun fakta menunjukkan kontroversi yang significan.

Kenaikan impor itu tidak terjadi tibatiba, importir telah mempelajari semua aspek tidak hanya tehnis, tapi termasuk kondisi infrastruktur, regulasi dan preferensi pasar hortikultura Indonesia sampai kepada struktur geografis dan demogarfis . Negara-negara produsen dan pengekspor komoditi hortikultura, sudah menyusun proyeksi yang matang terhadap potensi dan peluang pasar hortikultura Indonesia, baik jangka pendek, menengah maupun jangka panjang. Mereka sudah melakukan studi yang mendalam, tentang prospektif pasar hortikultura Indonesia. Mereka mengenal baik potensi hortikultura Indonesia, dan secara tehnis terdapat beberapa komoditas buah-buahan tidak bisa diproduksi Indonesia. Komoditikomoditi seperti buah jeruk, pir, kiwi, anggur, dll tidak bisa tumbuh dan berkembang dengan baik di negara-negara tropis seperti Indonesia. Yang menarik adalah impor bawang putih dan bawang merah, yang memiliki potensi cukup besar di Indonesia, tapi nilai impornya cukup signifikan, sehingga mengundang pertanyaan bagi berbagi pihak. Demikian pula untuk komoditi cabe, pisang, mangga, jeruk dan herbal yang telah dikembangkan oleh nenek moyang bangsa Indonesia sejak beberapa abad yang lalu.

Dari tahun 2010 - 2012, nilai import beberapa produk hotikultura didominasi oleh bawang putih 37,4\%, jeruk segar 25,6\%, Pir dan Kiwi 25,6\% dan bawang merah 9,04\% (tabel 5).

Harus diakui bahwa pembangunan hortikultura selama ini belum banyak kalau tidak bisa dikatakan tidak mendapat perhatian serius pemerintah. Secara kelembagaan penguatan hortikultura baru dalam waktu satu dasa warsa terakhir ketika dibentuk Direktorat Jenderal Hortikultura. Kelembagaan baru tersebut tidak bisa langsung tancap gas, tapi memerlukan waktu konsolidasi dan sosialisasi dipusat dan di daerah. Mungkin sampai saat ini masih banyak pejabat daerah bahkan juga mungkin di pusat yang belum tahu kalau ada Direktorat Jenderal Hortikultura, apalagi di Kabupaten nun jauh disana, dengan turn over pejabatnya sangat cepat. Undang-undang hortikultura juga baru berumur beberapa tahun dan turunan dari regulasi atau undang - undang tersebut dalam bentuk Peraturan Pemerintah, Keputusan Presiden, Keputusan Menteri dan Peraturan Daerah, belum seluruhnya diproses. Jika sudah dibuat, sosialisasinya sampai ke daerah dan kedunia usaha barangkali masih sangat terbatas dilakukan, sehingga sama halnya lembaganya, juga belum banyak dipahami oleh masyarakat. 
Tabel 5 : Nilai import beberapa komoditi hortikultura (2010-2012)

\begin{tabular}{lrrr}
\hline \multicolumn{1}{c}{ Komoditi } & 2010 & 2011 & 2012 \\
\hline Bawang merah & 33,86 & 75,52 & 26,74 \\
Bawang putih & 245,96 & 272,81 & 52,77 \\
Bawang bombay & 22,74 & 32,06 & 5,16 \\
Kentang segar & 14,59 & 46,41 & 6,72 \\
Cabe segar & 1,45 & 6,93 & 0,58 \\
Jeruk segar & 168,97 & 192,31 & 104,65 \\
Aggur segar & 81,27 & 113,11 & 267,50 \\
Apel segar & 168,0 & 186,40 & 34,58 \\
Pir \& Kiwi & 87,83 & 106,75 & 23,58 \\
Mangga \& Pisang & & sekitar 1 -2 juta US\$ & \\
\hline
\end{tabular}

Sumber : Kementerian Pertanian 2013.

*) januari s/d maret 2012.

Alokasi anggaran dari APBN untuk pembangunan hortikultura sangat terbatas, Investasi baik dalam bentuk PMDN maupun PMA sangat kecil meskipun telah banyak dilakukan promosi termasuk keluar negeri, karena berbagai kendala termasuk sifat komoditi yang verishabel dan beresiko tinggi, agak beda dengan komoditi perkebunan yang tahan lama seperti sawit, karet, kopi, teh, kelapa dll. Disamping itu nampaknya perbankan tidak banyak tertarik untuk memberikan kredit pada sektor pertanian apalagi untuk komoditi hortikultura. Dari sekitar Rp.2.200 trilyun kredit yang disalurkan oleh perbankan, yang dialokasikan kesektor pertanian hanya sekitar 5,4 persen (tabel 6).

Terjadi asimetris, antara pembiayaan perbankan dengan keinginan untuk membangun pertanian pada umumnya dan hortikultura nasional pada khususnya. Mereka yang bergerak dibidang usaha hortikultura, sangat kesulitan untuk mengakses kredit perbankan, dengan berbagai alasan dan pertimbangan. Hal ini menyebabkan para pelaku usaha agribisnis hortikultura kesulitan untuk mengembangkan dan melakukan ekspansi usaha baik secara vertikal maupun horizontal.

\section{Penanaman Modal Asing (PMA)} dan Penanaman Modal Dalam Negeri (PMDN) dihitung sejak diundangkan Undang-Undang Penanaman Modal tahun 1966/67 nilai investasi PMA dan PMDN untuk sektor pertanian hanya dikisaran 10 persen. Sementara itu APBN untuk sektor pertanian kurang dari 2\% dari total APBN. Dari angka2 tersebut menggambarkan bahwa energi sumber daya finansial yang dialokasikan untuk membangun pertanian termasuk hortikultura relatif kecil, sehingga berpengaruh linear terhadap kinerja pembangunan pertanian termasuk pembangunan hortikultura.

Dengan kondisi itu sulit diharapkan akselerasi pengembangan hortikultura, dan sulit untuk mengejar kemajuan negara lain, termasuk tidak bisa mengejar tuntutan preferensi masyarakat yang semakin meningkat. 
Tabel 6 : Akumulasi Kredit Perbankan Indonesia sampai Februari tahun 2012 (Milyar Rp)

\begin{tabular}{lrr}
\hline \multicolumn{1}{c}{ Sektor } & Jumlah Kredit & $\%$ \\
\hline Pertanian \& Perburuhan & 117.519 & 5,33 \\
Pertambangan & 85.017 & 3,85 \\
Perindustrian & 355.774 & 16,15 \\
Listrik, Gas \& Air & 52.069 & 2,36 \\
Konstruksi & 76.179 & 3,45 \\
Perdgn ,Hotel \& Rest. & 398.422 & 18,08 \\
Pengangkutan \& Gudang & 94.838 & 4,30 \\
Jasa sosial & 57.747 & 2,03 \\
Lainnya & 730.832 & 33,17 \\
Jumlah & 2.203 .024 & 100,00 \\
\hline
\end{tabular}

Sumber : Bank Indonesia 2013

Bukannya bermaksud mengecilkan arti produk hortikultura terutama buah2an dalam negeri, tapi coba kita bandingkan dan sandingkan jenis buah-buahan yang sama antara produk dalam negeri dengan produk impor yang ada dipasar-pasar modern, misalnya jeruk, apel, durian, anggur, mangga , pisang, dan lainnya, secara kasat mata buah lokal hampir semuanya kalah dengan performance buah2an impor. Sebagai bentuk kepedulian dan jiwa nasionalisme, pernah suatu ketika seorang pejabat memprotes toko swalayan karena di toko itu

produk buah2an impor ditampilkan dibagian depan semuanya dalam jejeran rak buah2an di toko tersebut, sementara buah lokal ditaruh dibelakang, tapi tetap saja tidak berpengaruh. Banyak juga jenis buah impor yang memang tidak bisa di produksi di Indonesia secara baik seperti buah pier,anggur, sawo, apel dan jeruk varitas tertentu, dll, sehingga hanya bisa didapatkan di pasar melalui impor dan itulah yang dipajang oleh toko atau pasar swalayan . Yang disayangkan adalah beberapa komoditi hortikultura impor tersebut sangat potensial untuk dikembangkan ditanah air seperti, jeruk, mangga, bawang merah dan bawang putih .

Gambaran diatas tidak lalu berarti bahwa tidak ada perkembangan hortikultura nasional,produksi komoditi hortikultura yang ditampilkan oleh BPS terus berkembang. Data dari Kementerian Pertanian menunjukkan angka2 pertumbuhan pertahun kentang $2,06 \%$, cabe $3,31 \%$, bawang merah 5,23\%, mangga $14,22 \%$, pisang $5,21 \%$, durian $8,77 \%$, jeruk $4,06 \%$, rimpang $7,28 \%$ dan anggrek $28,79 \%$. Ekspor produk hortikultura tertentu juga mengalami pertumbuhan, misalnya bunga potong, sayuran yang diekspor ke Singapura, mangga, salak, paprika, tanaman obat2an dll. Konsumsi perkapita juga meningkat baik dikota maupun dipedesaan. Oleh karena itu peningkatan impor produk hortikultura mengacu pada beberapa alasan. Pertama : tingkat pendapatan masyarakat Indonesia 
yang meningkat sehingga daya beli menjadi naik dan permintaan akan produk hortikultura terutama buah2an juga akan meningkat. Dengan tingkat pendapatan perkapita yang sudah mencapai US $\$ 4000$ tahun 2011 dibanding tahun 2007 yang baru mencapai sekitar US \$2000,maka adalah wajar terjadi peningkatan permintaan akan barang dan jasa. Elastisitas pendapatan terhadap permintaan komoditi hortikultura terutama buah2an memang cukup tinggi yaitu 0,8 , artinya bila pendapatan masyarakat naik sebesar $1 \%$, maka akan terjadi kenaikan permintaan akan buah2an sebesar $0,8 \%$. Hal ini merupakan penjelasan dari tingginya dan cenderung semakin tinggi permintaan akan buah2an. Dari data yang ada menunjukkan bahwa nilai impor jeruk segar, anggur segar, apel segar dan buah Pir \& Kiwi meningkat cukup significant (tabel 2). Jika dibanding dengan produk pertanian lainnya, elastisitas pendapatan terhadap permintaan komoditi hortikultura lebih tinggi dibanding dengan komoditas pangan lainnya kecuali daging dan produk ternak lainnya(tabel 7).

Tabel 7 : Elastisitas pendapatan terhadap permintaan produk pertanian global (19751985)

\begin{tabular}{lc}
\hline \multicolumn{1}{c}{ Komoditi } & Elastisitas \\
\hline Beras & 0,60 \\
Jagung & 0,20 \\
Ubi Kayu & 0,20 \\
Kacang tanah & 0,30 \\
Buah-buahan dan Kacang & 0,80 \\
Sayur-sayuran & 0,40 \\
Kopi & 0,20 \\
Teh & 0,60 \\
Lada & 0,50 \\
Gula & 1,10 \\
Daging & 1,60 \\
Telur & 1,20 \\
Susu & 2,00 \\
Ikan & 1,00 \\
Minyak Kedelai & 1,00 \\
\hline
\end{tabular}

Sumber ; Gary E Hansen, 1981
Selama ini konsumsi hortikultura masyarakat Indonesia relatif masih rendah jika dibandinggan negara Asean lainnya apalagi jika dibanding dengan negara maju seperti AS,Eropa dan Jepang . Sehingga dengan kenaikan pendapatan masyarakat mereka meningkatkan konsumsi produk hortikultura seperti buah2an, sayuran, tanaman hias, tanaman herbal dll (dalam teori ekonomi disebut marginal propensity to consume $=$ MPC masyarakat meningkat). Komoditi hortikultura buah dan sayuran yang memiliki elastisitas permintaan cukup tinggi, mengisyaratkan bahwa semakin tinggi tingkat pendapatan seseorang maka permintaan akan barang tersebut akan semakin naik pula. Oleh karena itu adalah suatu hal yang normal dan alami jika terjadi impor hortikultura ketika laju pertumbuhan permintaan lebih besar dari laju pertumbuhan suply dari produksi dalam negeri. Ini justeru menggambarkan bahwa masyarakat Indonesia betul-betul semakin meningkat pendapatan dan kesejahteraannya, bukan kenaikan pendapatan yang semu yang hanya ada dalam statistik. Kedua : produksi dalam negeri tidak mencukupi jumlah, jenis/ragam dan mutu sesuai dengan preferensi konsumen. Ketika pendapatan masyarakat meningkat maka preferensi konsumsi juga meningkat tidak hanya jumlahnya (kwantitas),tapi ragam/jenis dan kwalitasnya. Ketika pendapatan mereka masih rendah bahkan subsisten, mereka hanya mengkonsumsi produk hortikulura yang ada dan diproduksi disekitarnya dan yang terjangkau oleh daya belinya . Setelah 
pendapatan meningkat maka orang tersebut akan mencari dan tidak hanya membeli pisang misalnya, tapi juga sudah bisa membeli buah apel, buah mangga, pir dll. Sampai dititik ini, ketika secara agregat masyarakat sudah minded mengkonsumsi buah2an, maka para pedagang berusaha memenuhi permintaan tersebut, yang jika tidak bisa didapatkan dari dalam negeri, maka solusinya adalah dipenuhi melalui impor. Mungkin perlu dicatat bahwa sebagian besar jenis komoditi hortikultura impor yang kita saksikan jarang kita jumpai dikembangkan di tanah air secara ekonomi atau secara besar2an, pada umumnya hanya merupakan tanaman pekarangan dan kebun yang luasannya kecil. Banyak diantaranya tidak masuk dalam program pengembangan dan pembinaan, seperti pier, anggur, apel sayuran ekslusif, dll. Ketiga : kondisi geografis dan demografis Indonesia yang scarter, sebagian wilayah terutama kawasan timur Indonesia pengembangan komoditas hortikultura relatif belum terjamah secara mamadai, sehingga produk hortikultura lokal terbatas, penduduk dikawasan itu tergantung pada pasokan dari daerah lain atau impor. Bahkan beberapa wilayah yang infrastrukturnya terbatas, jauh dari pusat atau sentra produksi hortikultura, sehingga akses terhadap produk dalam negeri lebih sulit dibanding dengan produk impor baik secara fisik maupun finansial ,sehingga lebih menguntungkan mendatangkan produk hortikultura impor dibanding produk hortikultura dari dalam negeri, apalagi produk impor tersebut selain lebih murah, juga performancenya lebih baik.
Maraknya impor hortikultura sebetulnya dikhawatirkan akan menggeser produk hortikultura petani Indonesia yang secara umum belum siap menghadapi persaingan karena berbagai keterbatasan dan kelemahan antara lain, harga pokok yang tinggi, kwalitas rendah dan tidak homogen, produk musiman sehingga kontinyutas suply tidak terjamin, diperhadapkan dengan produk impor yang kwalitasnya lebih baik, proses produksinya lebih efisien, dan dapat tersedia sepanjang tahun. Dalam kondisi seperti itu, maka pemerintah harus melakukan intervensi melalui berbagai instrument agar produk hortikultura nasional dapat menjadi tuang dirumah sendiri. Dapat bersaing dengan produk impor, dan masyarakat lebih mencintai produk petani dalam negeri, sehingga sangat kecil ruang yang tersedia untuk impor. Namun disadari bahwa hal itu tidak mudah terutama di era globalisasi dimana ada kebebasan barang dan jasa untuk mengisi semua pasar yang tersedia. Disamping pembinaan dan pengembangaan komoditi hortikultura agar bisa berkembang secara significan, juga diperlukan upaya2 konkrit untuk membendung impor itu sendiri. Karena tanpa ada upaya tersebut maka kedepan akan semakin marak impor produk hortikultura tersebut, dan ini bisa menyengsarakan masyarakat petani.

\section{STRATEGI PENGENDALIAN IMPOR}

Setiap negara tidak mungkin secara alami dapat memenuhi seluruh kebutuhan barang dan jasa hanya dari produksi dalam negeri. Membutuhkan supply dari negara lain dalam bentuk impor untuk barang 
tertentu, sehingga berkembang perdagangan antar negara dalam bentuk ekspor impor. Indonesia sebagai negara tropis dan agraris, meskipun memiliki potensi sumber daya alam dan kekayaan genetik yang besar, namun tetap saja harus mengimpor produk-produk pertanian tertentu termasuk produk hortikultura untuk memenuhi kebutuhan permintaan dalam negeri.

Secara umum strategi pengendalian impor dilakukan melalui strategi promosi dan proteksi. Strategi promosi dilakukan melalui upaya untuk meningkatkan supply dengan meningkatkan pproduksi dalam negeri, baik volume maupun kualitas produksi serta melakukan diversifikasi produk melalui pengembangan tehnologi baik produk primer maupun produk olahannya. Upaya lain dalam rangka strategi promosi adalah dibidang perdagangan dan investasi, melalui regulasi yang kondusif untuk perkembangan produksi hortikultura dalam negeri. Penerapan bea masuk produk sejenis, rasionalisasi pajak ekspor, perbaikan infrastruktur logistik dan perdagangan, pelayanan birokrasi yang efektif dan efisien merupakan langkah-langkah efektif untuk mendorong kinerja produk hortikultura. Selanjutnya kebijakan dibidang investasi seperti kemudahan dalam investasi, tax holiday, insentif di budidaya, tingkat suku bunga bank yang kondusif merupakan instrumen yang diharapkan dapat mendorong kinerja pengembangan hortikultura dalam negeri.

Strategi promosi lainnya adalah penguatan kelembagaan hortikultura, baik kelembagaan pemerintah, petani dan bisnis hortikultura. Regulasi untuk mengakslerasi kinerja hortikultura nasional memang sudah ada undang-undang hortikultura, tapi kebijakan turunannya belum banyak dikeluarkan sehingga implementasi dari undang-undang tersebut belum dapat dilakukan. Strategi promosi lainnya adalah pemasaran yang efektif, produktif dan efisien. Jaringan pasar komoditi harus dibangun tidak hanya di luar negeri tapi juga di dalam negeri. Pengembangan jaringan pasar produk hortikultura harus dibangun dan dikembangkan mulai dri pedesaan sebagai basis produksi, sampai ditingkat kecamatan, kabupaten, propinsi dan secara nasional. Di pasar ekspor haru dikembangkan trading house dan perwakilan dagang yang dapat memromosikan produk-produk hortikultura nasional. Pameran yang bersifat regional dan internasional harus diintensifkan yang difasilitasi oleh pemerintah.

Strategi proteksi, dilakukan tidak hanya melalui perlindungan terhadap produksi hortikultura nasional, tapi juga proteksi secara filosofis dalam berbagai bentuk. Salah satu diantaranya adalah melalui gerakan kecintaan dan kebanggaan terhadap produk hortikultura dalam negeri, memperkuat nasionalisme melalui penggunaan dan konsumsi produk dalam negeri. Selain itu, proteksi juga dilakukan dengan memperkuat daya tangkal produkproduk hortikultura nasional, sekaligus sebagai bentuk peningkatan daya saing. Seperti diketahui bahwa daya saing produk hortikultura tidak bisa dipisahkan dari daya saing bangsa, daya saing ekonomi nasional. 
Dalam laporannya, mengenai iklim daya saing Indonesia tahun 2006, USDA melalui program Senada menjelaskan bahwa terdapat 9 komponen yang menentukan daya saing suatu bangsa yaitu, institusi, infrastruktur, makroekonomi, kesehatan dan pendidikan utama, pendidikan dan pelatihan lebih tinggi, efisiensi pasar, kesiapan tehnologi, pengalaman bisnis dan inovasi. Dibandingkan dengan negaranegara Asean, China dan Korea, Indonesia masih jauh ketinggalan dalam daya saing. Pembuktian empiris dari haslmpenelitian itu memang terasa di berbagai sektor eknomi termasuk hortikultura.

Yang menjadi perhatian dan keprihatinan semua kalangan adalah komoditi hortikultura yang sesungguhnya bisa diproduksi dalam negeri, tapi karena tidak dikembangkan secara baik sehingga produksinya rendah dan akibatnya kebutuhan masyarakat dipenuhi dari impor. Simplifikasi beberapa upaya yang dapat dilakukan untuk membendung impor produk hortikultura adalah :

\section{Penguatan daya tangkal}

Penguatan daya tangkal pada prinsipnya merupakan upaya untuk memperkuat kemampuan komoditi itu sendiri untuk bersaing dengan produk impor, yang meliputi ; a) perbaikan kwalitas produk, sehingga dapat menyaingi kwalitas produk impor. Hal ini dapat dilakukan melalu perbaikan varietas, menerapkan Good Agricultural Practices (GAP), perbaikan penanganan pasca panen, perbaikan sistim pengemasan dan pengepakan, perbaikan sistim transportasi dan penyimpanan, pengembangan quality control secara efektif dan sistim produksi zero waste. b) efisiensi produksi, yang bermuara pada harga pokok dan harga jual yang lebih rendah. Hal ini dapat dilakukan melalui peningkatan produktivitas, dengan menggunakan bibit unggul, penggunaan pupuk, perbaikan sistim irigasi dan drainase, menekan angka kehilangan hasil, pemberantasan hama penyakit, dan c) kontinyutas supply, yaitu bahwa produksi hortikultura nasional harus tersedia dalam jumlah yang cukup sepanjang tahun dan dapat diakses secara fisik dan secara ekonomis oleh masyarakat. Selama ini produk hortikultura pada umumnya bersifat musiman, sehingga diluar musim produk tersebut tidak tersedia di pasar. Untuk itu perlu diatur pola tanam, perbaikan varietas agar terdapat produksi sepanjang tahun. Melalui upaya-upaya tersebut diharapkan produk hortikultura Indonesia dapat bersaing dengan produk-produk hortikultura impor, dan dapat memotivasi petani untuk mengembangkan komoditi hortikultura.

\section{Kebanggaan dan kecintaan terhadap produksi hortikultura dalam negeri.}

Pemerintah harus dapat mendorong masyarakat untuk mencintai dan bangga terhadap produk hortikultura dalam negeri, nasionalisme dalam mengkonsumsi produk dalam negeri harus menjadi budaya bangsa. Import minded bagi sebagian masyarakat Indonesia terutama mereka yang berpendapatan tinggi perlu dimotivasi melalui sosialisasi kecintaan dan kebanggan terhadap produk hortikultura dalam negeri. Gerai penjualan dan supermarket juga harus 
didorong untuk mempromosikan produk hortikultura dalam negeri dengan memberikan perlakuan yang terbaik, misalnya jangan dipajang dibelakang dalam jejeran produk-produk hortikultura yang dipasarkan. Fanatisme terhadap produk hortikultura dalam negeri merupakan energi sosial yang kuat untuk membangun hortikultura nasional, dan menjadikan tuan di rumah sendiri.

\section{Non tarif barrier}

Instrumen lain yang bisa digunakan untuk membendung impor proda uk hortikultura adalah dengan menggunakan non tarif barrier. Diantaranya dengan menggunakan instrumen SPS dan safeguard. Dengan alasan kesehatan, hama dan penyakit, serta keamanan pangan maka instrumen SPS dapat digunakan untuk melarang masuknya produk hortikultura ke Indonesia. Contoh yang baik seperti penyakit mulut dan kuku (PMK) pada ternak sapi yang dilarang diimpor dari negara yang tidak bebas dari penyakit tersebut. Larangan impor juga dapat dilakukan jika ditengarai berdasarkan scientific evidence bahwa produk impor tersebut dapat mematikan usaha sejenis didalam negeri dengan instrumen safeguard. Termasuk dalam kategori ini adalah impor yang bersifat dumping. Uapaya lain adaah dengan mewajibkan importir hanya menggunakan pelabuhan tertentu yaang ditentukan oleh emerintah, sehingga memudahkan pengawasan dan pengendalian.

\section{Instrumen tarif}

Melalui pengenaan tarif bea masuk, mengandung beberapa implikasi, yaitu bahwa produk impor akan meningkat harganya menyesuaikan dengan besarnya tarif bea masuk. Dengan demikian produk dalam negeri dapat bersaing dengan prorduk impor tersebut. Pengenaan tarif bea masuk juga akan memberikan pendapatan bagi negara. Bea masuk juga akan mengurangi margin yang diterima oleh importir, sehingga tidak cukup kuat untuk memotivasi dalam melakukan impor.Selama ini Indonesia juga dibanjiri oleh produk impor karena tarif bea masuk pada umumnya rendah, sehingga dengan sangat leluasa produk hortikultura dari luar membanjiri pasar dalam negeri.

\section{Pengawasan}

Indonesia sebagai negara kepulauan, memiliki pelabuhan pintu masuk yang cukup banyak, sehingga memudahkan masuknya produk-produk hortikultura ke dalam negeri baik secara legal maupun ilegal. Pengawasan pintu-pintu masuk merupakan suatu upaya untuk mencegah produk-produk yang masuk dengan tidak mengikuti prosedur dan ketentuan yang berlaku. Saat ini pengawasan dipelabuhan terutama yang terpencil dan diperbatasan sangat minim, baik personil maupun sarana dan prasarana. Petugas pabean, karantina dan imigrasi seringkali hanya diprioritaskan pada pelabuhan-pelabuhan besar, sedangkan dipelabuhan kecil terbatas jumlahnya. Penerapan ketentuan terhadap keluar masuk barang dipelabuhan harus 
diperketat melalui kordinasi lembaga yang terkait.

\section{Larangan impor.}

Pilihan terakhir untuk membendung impor adalah dengan penetapan larangan impor bagi komoditi hoertikultura tertentu untuk masuk ke Indonesia. Larangan ini akan mengundang debat pro contra dan bahkan protes dari negara-negara lain. Protes juga mungkin datang dari masyarakat konsumen itu sendiri yang merasa haknya terganggu karena larangan tersebut.

\section{KESIMPULAN}

Dalam era globalisasi, perdagangan barang dan jasa termasuk produk hortikultura, dihadapkan pada tantangan untuk menghadapi persaingan yang semakin ketat. Bagi negara berkembang seperti Indonesia yang memiliki potensi sumber daya alam yang besar untuk pengembangan hortikultura,dituntut untuk membangun dan mengembangkan strategi untuk mengendalikan impor produk-produk hortikultura, untuk memberi ruang gerak yang leluasa bagi produk dalam negeri untuk menjadi pemain utama di pasar domestik, baik karena pertimbangan ekonomi, sosial, dan kemandirian bngsa. Strategi promosi dan proteksi yang disederhanakan menjadi lima upaya pengendalian impor hortikultura perlu dirumuskan aplikasi dan operasionalisasinya, yang dipedomani oleh semua pihak di pusat dan daerah. Melalui strategi tersebut diharapkan produk hortikultura nasional dapat menjadi tuan dirumah sendiri, karena memiliki kemampuan bersaing yang tinggi.

\section{DAFTAR PUSTAKA}

Anonimous, 2006, Iklim Daya Saing Indonesia, USAID SENADA, Jakarta

,2009, Direktori Pengolahan dan Pemasaran Hasil Pertanian, Kementerian Pertanian.

2012, Statistik Pertanian, Kementerian Pertanian,Jakarta 2011, Statistik Indonesia, Badan Pusat Statistik,Jakarta

Andi Nuhung,Iskandar, 2003, Membangun Pertanian Masa Depan, Aneka Ilmu Semarang 2006, Bedah Terapi Pertanian Nasional, BIP/Gramedia, Jakarta

Amir,M.S, 2000, Seluk Beluk Perdagangan Luar Negeri, PPM Jakarta

Banbang Irawan, 2007, Fluktuasi Harga, Transmisi Harga Dan Marjin Pemasaran Sayuran, Analisis Kebijakan Pertanian, Vol.5 No.4, Desember 2007.

Bill Scott, 1993, Strategi dan Tehnik Negosiasi, PT Pustaka Binaman Pressindo Jakarta.

Joseph E.Stiglitz, 2006, Making Globalization Work, Mizan Bandung.

Kotler \& Armstrong, 2001, Prinsip-Prinsip Pemasaran, Erlangga, Jakarta. 
Michael E.Porter,2008, Competitive Advantage, Karisma Publishing Group.

Miltiades Chacholiades, 1975, International Trade, Theory and Policy, Mc Graw-Hill Book Company.

Mudradjad Kuncoro, 2013, Indikator Ekonomi, UPP-STIM, YKPM.

Nikos Alexandratos (editor), 1995, World Agriculture ; Toward 2010, FAO

Rainer Schickele,1954, Agricultural Policy, University of Nirbaska Press,Lincoln.

Richard E.Caves \& Ronald W.Jones, 1981, World Trade and Payments, Little, Brown and Company, Boston.

Sri Hery Susilowati, 2008, Strategi Agricultural-Demand-led-
Industrialization Dalam Perspektif Peningkatan Kinerja Ekonomi Dan Pendapatan Petani, Forum Penelitian Agro Ekonomi, Vol.26 No.1 Juli 2008.

Sri Nuryanti, 2010, Peluang dan Ancaman Perdagangan Produk Pertanian dan Kebijakan Untuk Mengatasinya, , Analisis Kebijakan Pertanian, Volume 8 no. 3 September 2010.

Syahyuti, 2008, Peran Modal Sosial Dalam Perdagangan Hasil Pertanian, Forum Penelitian Agro Ekonomi, FAE, Vol.26 No.1 Juli 2008.

Tulus T.H. Tambunan, 2011, Perekonomian Indonesia, Ghalia Indonesia.

*Dosen Program Magister Agribisnis UIN Syarif Hidayatullah Jakarta 
